\title{
AMBIVALENT EFFECT OF LONG LASTING TERGURIDE TREATMENT ON GENETICALLY BASED GLYCIDE AND LIPIDE METABOLISM ABNORMALITIES IN SHR/N-cp KOLETSKY RATS
}

\author{
Věroslav Golda \\ Institute of Experimental Neurosurgery, Charles University, Faculty of Medicine and Teaching Hospital, Hradec Králové; \\ (Head: doc. MUDr. J. Náhlovský, CSc.)
}

\begin{abstract}
Summary: Experiments were carried out in the genetically hypertensive obese rats of Koletsky type (SHR/N-cp obese), in their lean siblings (SHR/N-cp lean) and in the rats of Han-Wistar strain. The effect of long lasting terguride treatment was monitored when the animal represents a control for itself. Blood was sampled to heparinized capillaries from retrobulbar plexus in the same animal before and after the terguride treament. Long lasting terguride treatment shows decrease in ,area under the glucose tolerance curve" in all groups of animals,increase in glycaemia in normotensive males,increase in insulinemia in normotensive rats of both sexes and in SHR/N-cp lean males and decrease of insulinemia in SHR/N-cp obese males, increase of triglyceridemia in normotensive rats of both sexes and in SHR/N-cp lean males, and decrease of triglyceridemia in SHR/N-cp lean females and SHR/N-cp obese of both sexes, increase in cholesterolemia in normotensive and $\mathrm{SHR} / \mathrm{N}$-cp lean males, decrease in cholesterolemia in normotensive, SHR/N-cp lean and obese females. Thus ambivalent effect of terguride treatment is more expressive in glucose tolerance and in plasma triglycerides.Ambivalent effect of long lasting terguride treatment is profoundly expressed in correlation between pre-treament state of individual parameters and the effect of treatment expressed in percentage changes in post-treatment state. In all cases statistically significant correlation coefficients show negative mark. Thus it is apparent that terguride increases monitored parameter when this parameter is low before treatment, and vice versa.When it is considered „area under the glucose tolerance curve“,significance was attained in all groups, when judging basal glycaemia, significance was attained in normotensive and SHR/N-cp lean rats of both sexes,taking into account insulinemia,significance was attained in normotensive and SHR/N-cp obese rats of both sexes, when analysing plasma triglycerides,significance was attained in normotensive rats of both sexes and in SHR/Ncp lean females and obese males, when we consider total plasma cholesterol, significance was attained in normotensive rats of both sexes and in SHR/N-cp lean males. From the clinical point of view it must be underlined that terguride is potent to increase insulinemia. Thus there is open a possibility of the other clinical indication of the mentioned drug.
\end{abstract}

Key words: SHR of Koletsky type; Triglycerides; Total plasma cholesterol; Basal glycaemia; Glucose tolerance; Insulinemia; Ambivalent effect of Terguride

\section{Introduction}

In our previous paper (3) we have documented ambivalent effect of terguride when the drug was applied in normotensive rats of Han-Wistar strain and in SHR/N-cp obese and lean Koletsky rats.The mentined ambivalent effect of terguride was found when plasma triglycerides, total plasma cholesterol and glucose intolerance were considered, i.e., in the group with low parameters terguride shows increase, and vice versa.

While in the above mentioned study the effect of terguride was considered when the results in control and experimental groups were compared, then in the other study where the patients suffering from hyperlipemia accompani- ed by glucose intolerance the effect of the mentioned drug was monitored in the same patient before treatment and after three months terguride treatment (4), the patient represented a control for himself. Terguride remained without effect or was very low in the patients where no or minimal abnormalities in glucose tolerance were found, and vice versa. For instance, the most profound alleviating effect of terguride was found when before treatment the greatest glucose intolerance was detected. Similar ambivalent effect of terguride was documented in the dislipemia (4).

In the recent study we are verifying the last mentioned results but the measurements were performed in animals where hyperlipemia and the glucose intolerance is based genetically, i.e., in SHR/N-cp obese and lean Koletsky rats. 
The normotensive rats of Han-Wistar strain were monitored as well. In recent experiments the animal represents a control for itself.

\section{Material and methods}

\section{Animals}

Experiments were carried out in the normotensive HanWistar rats as well as in obese and lean genetically hypertensive SHR/N-cp rats (5) of both sexes. Lean SHR/N-cp rats represents dominant non-obese homozygotes and heterozygotes whereas their obese siblinggs are recessive homozygotes $(\mathrm{cp} / \mathrm{cp})$. The abnormal animals were obtained by Koletsky (75) when mating a female spontaneously hypertensive rat (Okamoto-Aoki strain) with normotensive Sprague-Dawley male rat. The genetically obese animals appeared after several generations of selective inbreeding of hypertensive offsprings of the original cross.

The blood pressure (measured by an indirect method) attained in lean genetically hypertensive SHR/N-cp males $24.61 \pm 2.22 \mathrm{kPa}(\mathrm{n}=15), 17.60 \pm 1.32 \mathrm{kPa}(\mathrm{n}=8)$ in females, and in Han-Wistar males $15.90 \pm 0.62 \mathrm{kPa}(\mathrm{n}=7)$, $14.38 \pm 1.22 \mathrm{kPa}$ in females (2) The obese genetically hypertensive $\mathrm{SHR} / \mathrm{N}$-cp rats show comparable blood pressure (5).

After weaning at the age of 30 days the animals were kept in groups of four and supplied with water and DOS$2 \mathrm{~b}$ pelleted diet ad libitum. During the experiment the animals were kept in groups of two. Body weight, water and pellet intake was daily controlled (except Saturdays and Sundays).

\section{Plasma lipids}

Blood was sampled to heparinized capillaries (from retrobulbar plexus under light ether anaesthesia at 07.00 a.m.after $14 \mathrm{~h}$ starvation) before and after 21 day terguride treatment.Blood was centrifuigated and the serum stored at $-20^{\circ}$ C.Enzymatic colorimetric method was used for the determination of total plasma cholesterol (CHOD-PAPBoeringer)as well as for determination of plasma triglycerides (GPO-PAP-TRIG-Boehringer). Estimation was made by Hitachi analyzer.

\section{Plasma insulin}

Plasma insulin was estimated by radioimmunoassay.

\section{Glucose tolerance and basal glycaemia}

Blood was sampled to heparinized capillaries (from retrobulbar plexus under light ether anaesthesia) before glucose loading ( basal glycaemia) as well as 30,60,120 and 180 min after glucose loading. Glucose $(3 \mathrm{~g} / \mathrm{kg}$ b.w., $30 \%$ solution) was applied intragastrically after $14 \mathrm{~h}$ starvation. Glycaemia was estimated enzymatically (Oxochrom glucose, Lachema). Glucose tolerance is expressed as a sum of glycaemia obtained 30,60,120 and 180 min after glucose loading („area under the glucose tolerance curve“).

\section{Terguride treatment}

The drug was applied i.p. in two daily doses (07.00 and 14.00) for 21 days. Terguride maleate was administered at a dose of $0.1 \mathrm{mg} / \mathrm{kg}$.

\section{Statistics}

The data were analyzed by the Wilcoxon test for matched pairs when we were looking for the long lasting terguride effect in individual groups and individual parameters. Moreover, correlations were computed between pre-treatment level of individual parameters and post-treatment level which was monitored in the same animal.

Thus the animal serves as a control for itself when the effect of terguride treatment was calculated. The effect was expressed in percent when the value obtained in pre-treatment was considered as $100 \%$. Statistical significance of value remoteness in the individual groups was controlled by the Dixon test (1). The values reaching statistical sinificance of remoteness from the other values in a group we not considered in statistical evaluation.

\section{Results}

Glucose tolerance (Table l)

Terguride decreases the ,area under the tolerance curve" in all groups of animals.

Basal glycaemia (Table l)

Terguride increases basal glycaemia in normotensive males.

Table l: Effect of long lasting terguride treatment on glucose tolerance and basal glycaemia

\begin{tabular}{|l|c|c|c|c|}
\hline Group & $\mathrm{n}$ & drug & glucose tolerance & glycaemia \\
\hline NR-M & 10 & Co & $24.48 \pm 2.53$ & $3.03 \pm 0.39$ \\
& 10 & Te & $21.12 \pm 1.49^{\mathrm{d}}$ & $3.52 \pm 0.55^{\mathrm{b}}$ \\
\hline NR-F & 8 & $\mathrm{Co}$ & $28.05 \pm 2.53$ & $3.63 \pm 0.50$ \\
& 8 & $\mathrm{Te}$ & $22.39 \pm 1.16^{\mathrm{d}}$ & $3.14 \pm 0.66$ \\
\hline SHR-M & 8 & $\mathrm{Co}$ & $33.22 \pm 3.41$ & $5.01 \pm 0.66$ \\
& 8 & $\mathrm{Te}$ & $25.96 \pm 0.21^{\mathrm{d}}$ & $4.62 \pm 0.33$ \\
\hline SHR-F & 8 & $\mathrm{Co}$ & $33.94 \pm 3.96$ & $4.57 \pm 0.61$ \\
& 8 & $\mathrm{Te}$ & $26.07 \pm 3.25^{\mathrm{d}}$ & $4.90 \pm 0.33$ \\
\hline SHR-O-M & 8 & $\mathrm{Co}$ & $52.64 \pm 16.67$ & $4.29 \pm 0.94$ \\
& 8 & $\mathrm{Te}$ & $31.74 \pm 12.16^{\mathrm{d}}$ & $4.51 \pm 1.05$ \\
\hline SHR-O-F & 12 & $\mathrm{Co}$ & $36.74 \pm 4.02$ & $5.12 \pm 0.88$ \\
& 12 & $\mathrm{Te}$ & $25.08 \pm 2.04^{\mathrm{d}}$ & $4.95 \pm 0.88$ \\
\hline
\end{tabular}

Table 1. Means and standard deviations. Abbreviations: Co- control animals, Te - animals under terguride treatment. a - $\mathrm{P}<0.10, \mathrm{~b}-\mathrm{P}<0.05$, c $\mathrm{P}<0.02$, d - $\mathrm{P}<0.01$. NR - Wistar strain, SHR - SHR/N-cp lean, SHR-O SHR/N-cp obese, $\mathrm{M}$ - males, F - females.

\section{Insulinemia (Table 2)}

Terguride increases insulinemia in the normotensive rats of both sexes and in SHR/N-cp lean males. Insulinemia is decreased at the level of trend $(\mathrm{P}<0.10)$ in SHR/N-cp obese males. 
Triglycerides (Table 2)

Terguride increases triglycerides in normotensive rats of both sexes and in SHR/N-cp lean males. It decreases triglycerides in SHR/N-cp lean females and in SHR/N-cp obese rats of both sexes.

\section{Total plasma cholesterol (Table 2)}

Terguride increases cholesterol in normotensive males and in SHR/N-cp lean males and decreases SHR/N-cp obese as well as lean females.

Table 2: Effect of long lasting terguride treatment on insulinemia, triglyceridemia and cholesterolemia.

\begin{tabular}{|l|c|c|l|l|l|}
\hline Group & $\mathrm{n}$ & drug & insulinemia & triglyceridemia & $\begin{array}{c}\text { cholestero- } \\
\text { lemia }\end{array}$ \\
\hline NR-M & 10 & Co & $127 \pm 23$ & $1.11 \pm 0.09$ & $1.82 \pm 0.29$ \\
& 10 & Te & $219 \pm 55^{\mathrm{d}}$ & $1.29 \pm 0.19^{\mathrm{b}}$ & $2.02 \pm 0.16^{\mathrm{b}}$ \\
\hline NR-F & 8 & Co & $114 \pm 18$ & $0.87 \pm 0.14$ & $2.24 \pm 0.22$ \\
& 8 & $\mathrm{Te}$ & $153 \pm 18^{\mathrm{d}}$ & $1.12 \pm 0.08^{\mathrm{d}}$ & $1.96 \pm 0.2^{\mathrm{a}}$ \\
\hline SHR-M & 8 & Co & $157 \pm 20$ & $0.74 \pm 0.13$ & $2.31 \pm 0.17$ \\
& 8 & Te & $202 \pm 34^{\mathrm{d}}$ & $1.36 \pm 0.28^{\mathrm{d}}$ & $2.59 \pm 0.16^{\mathrm{d}}$ \\
\hline SHR-F & 8 & Co & $140 \pm 22$ & $1.64 \pm 0.76$ & $3.84 \pm 0.77$ \\
& 8 & Te & $140 \pm 40$ & $1.03 \pm 0.19^{\mathrm{d}}$ & $3.23 \pm 0.55^{\mathrm{d}}$ \\
\hline SHR-O-M & 7 & Co & $857 \pm 461$ & $3.81 \pm 0.59(6)$ & $2.85 \pm 0.30$ \\
& 7 & $\mathrm{Te}$ & $457 \pm 141^{\mathrm{a}}$ & $3.28 \pm 0.35(6)^{\mathrm{b}}$ & $2.97 \pm 1.03$ \\
\hline SHR-O-F & 12 & Co & $438 \pm 168$ & $7.22 \pm 1.30$ & $3.52 \pm 0.27$ \\
& 12 & $\mathrm{Te}$ & $397 \pm 128$ & $3.06 \pm 0.66^{\mathrm{d}}$ & $2.30 \pm 0.45^{\mathrm{d}}$ \\
\hline
\end{tabular}

Table 2. Means and standard deviations. Abbreviations are the same as in Table 1 and in Table 3.

Drug state dependent effect - glucose tolerance (Table 3)

In all groups of animals there are statistically significant correlations (irrespective of test which was used, i.e., parametric or non-parametric). In all cases there is a negative correlation coefficient.

Table 3: State dependent effect of long lasting terguride treatment on glucose tolerance and glycaemia

\begin{tabular}{|l|c|l|c|c|}
\hline Group & $\mathrm{n}$ & drug & glucose tolerance & glycaemia \\
\hline NR-M & 10 & Spe & $-0.7234^{\mathrm{b}}$ & $-0.8580^{\mathrm{d}}$ \\
& & Pea & $-0.8549^{\mathrm{d}}$ & $-0.7065^{\mathrm{b}}$ \\
\hline NR-F & 8 & Spe & $-0.8434(9)^{\mathrm{d}}$ & -0.5334 \\
& & Pea & $-0.9416(9)^{\mathrm{d}}$ & $-0.709^{5} \mathrm{~b}$ \\
\hline SHR-M & 8 & Spe & $-0.8434^{\mathrm{c}}$ & $-0.8051^{\mathrm{b}}$ \\
& & Pea & $-0.9671^{\mathrm{d}}$ & $-0.9381^{\mathrm{d}}$ \\
\hline SHR-F & 8 & Spe & $-0.7857^{\mathrm{b}}$ & $-0.8295^{\mathrm{b}}$ \\
& & Pear & $-0.7256^{\mathrm{b}}$ & $-0.8529^{\mathrm{d}}$ \\
\hline SHR-O-M & 9 & Spe & $-0.8619^{\mathrm{d}}$ & $-0.3810(8)$ \\
& & Pear & $-0.7678^{\mathrm{c}}$ & -0.4218 \\
\hline SHR-O-F & 12 & Spe & $-0.7088^{\mathrm{c}}$ & -0.3322 \\
& & Pear & $-0.7581^{\mathrm{d}}$ & -0.4349 \\
\hline
\end{tabular}

Table 3. Correlation coefficients. Abbreviations: Spe - Spearman nonparametric correlation, Pear - Pearson pararametric correlation. $n=$ number of rats in group. The other abbreviations are the same as in Table 1 and in Table 2 .
Drug state dependent effect - basal glycaemia (Table 3)

Statistically significant correlations with negative correlation coefficients (irrespective of the test) were found in normotensive as well as in SHR/N-cp lean rats of both sexes. Significance is missing in the SHR/N-cp obese rats of both sexes.

\section{Drug state dependent effect - insulinemia (Table 4)}

Statistically significant correlations with negative correlation coefficients were found in SHR/N-cp obese rats of both sexes (irrespective of the test). Statistically significant correlations were found also in normotensive rats of both sexes when parametric Pearson test was used.

\section{Drug state dependent effect - triglycerides (Table 4)}

Statistically significant correlations with negative correlation coefficients were found in the normotensive rats of both sexes and in SHR/N-cp lean females and SHR/N-cp obese males (irrespective of test).

\section{Drug state dependent effect - cholesterol (Table 4)}

Statistically significant correlation with negative correlation coefficients were found (irrespective of test) in normotensive males and in SHR/N-cp lean males, and in normotensive females when parametric test was used.

Table 4: State dependent effect of long lasting terguride treatment in insulinemia, triglyceridemia and total plasma cholesterol

\begin{tabular}{|l|c|l|l|l|l|}
\hline Group & $\mathrm{n}$ & drug & insulin. & triglycer. & cholesterol \\
\hline NR-M & 10 & Spe & -0.6121 & $-0.6544^{\mathrm{b}}$ & $-0.9030^{\mathrm{d}}$ \\
& 10 & Pea & $-0.6833^{\mathrm{b}}$ & $-0.6358^{\mathrm{b}}$ & $-0.8694^{\mathrm{d}}$ \\
\hline NR-F & 8 & Spe & $-0.6946^{\mathrm{a}}$ & $-0.8133^{\mathrm{b}}$ & -0.6190 \\
& 8 & Pea & $-0.7292^{\mathrm{c}}$ & $-0.8566^{\mathrm{d}}$ & $-0.7068^{\mathrm{b}}$ \\
\hline SHR-M & 8 & Spe & -0.4286 & -0.4048 & $-0.8614^{\mathrm{d}}$ \\
& & Pear & -0.5658 & -0.2843 & $-0.8208^{\mathrm{c}}$ \\
\hline SHR-F & 8 & Spe & +0.0476 & $-0.9048^{\mathrm{d}}$ & -0.5476 \\
& & Pear & +0.2391 & $-0.8629^{\mathrm{d}}$ & -0.5667 \\
\hline SHR-O-M & 7 & Spe & $-0.9643^{\mathrm{d}}$ & $-0.8286(6)^{\mathrm{a}}$ & +0.6429 \\
& & Pear & $-0.8846^{\mathrm{d}}$ & $-0.8580(6)^{\mathrm{b}}$ & +0.3586 \\
\hline SHR-O-F & 12 & Spe & $-0.7483^{\mathrm{c}}$ & 0.3462 & +0.0911 \\
& & Pear & $-0.7358^{\mathrm{d}}$ & 0.4362 & +0.0861 \\
\hline
\end{tabular}

Table 4. Correlation coefficients. Triglycer. - plasma triglycerides, Cholester. -total plasma cholesterol. The other abbreviations are the same as in Table 1 and Table 3.

\section{Discussion}

Data obtained in the recent series of experiments are consistent with the findings mentioned in the introduction $(3,4)$,i.e., long lasting terguride treatment of lipide and glycide metabolic abnormalities shows ambivalent effect. We demonstrated this ambivalent effect of the mentioned drug in the SHR/N-cp obese and lean Koletsky rats when the control animals were compared with experimental animals 
(3) as well as in the patients suffering with hyperlipemia accompanied by glucose intolerance (4),where the patient was a control for himself.

In the recent series of experiments the animal represents a control for itself, i.e., we are using the same experimental arrangement as it was used in the monitoring the effect of long lasting effect of terguride in the patients suffering with glycide and lipide abnormalities (4) with three exceptions,i.e., terguride in the patients was applied for three months (in our series of experiments the drug was applied for three weeks only) moreover, the dose per day was in the patients $0.6 \mathrm{mg}$ and was applied per os (in our rats drug was applied i.p.).

When we compare intergroup differences in the effect of long lasting terguride treatment the most expressed ambivalent effect can be found in glucose tolerance and in plasma triglycerides (see Table 1 and 2). When pre-treatment „area under the glucose tolerance curve“ represents in normotensive males $24.48 \mathrm{mmol} / \mathrm{l}$, in SHR/N-cp lean males $33.22 \mathrm{mmol} / 1$ and in SHR/N-cp obese males $52.64 \mathrm{mmol} / 1$, then the terguride effect shows in normotensive males-14\%, in SHR/N-cp lean males $-22 \%$ and in SHR/N-cp obese males $-32 \%$.Similarly the ambivalen effect of terguride treatment is expressed in plasma triglycerides. When pretreatment plasma triglycerides represent in normotensive females $0.87 \mathrm{mmol} / \mathrm{l}$, in SHR/N-cp lean females 1.64 $\mathrm{mmol} / 1$ and in SHR/N-cp obese females $7.22 \mathrm{mmol} / 1$, then the terguride effect is represented in normotensive females by $+30 \%$, in SHR/N-cp lean females by $-28 \%$ and in SHR/Ncp obese females by $-57 \%$.

The above mentioned ambivalent effect of terguride treatment when individual groups of animals are considered can be explained by strain and/or substrain effect. There is also apparent the sex dependence of ambivalent effect which is more expressed in males when glucose tolerance is considered, and in females when plasma triglycerides are analyzed. When the results in individual groups are taken into consideration, then ambivalent effect of terguride is problematical in insulinemia and in total plasma cholesterol. Under these computation arrangement,i.e., when pre- and post-treatment data are compared, the effect of terguride in basal glycaemia is limited to the normotensive males.

The ambivalent effect can be proved also by computation of correlations between the pre-treatment values in some parametr and the terguride effect expressed in per cent (100\% is equal to pre-treament value). The results are summarized in Table 3 and 4.

First, it must be stressed that all statistically significant correlation coefficient show negative marks, i.e., it is in agreement with the data presented in our previous papers $(3,4)$ as well as in the recent study when the results of individual groups were considered (see glucose tolerance and plasma triglycerides, Table 1 and 2),i.e., the greater pre-treatment value the greater effect of long lasting terguride treatment, and vice versa.
Moreover, statistically significant correlation coefficient can be found also in the cases where differences between control and experimental group do not attained statistical significance. Most apparent differences in the statistical significance can be demonstrated in basal glycaemia. While Wilcoxon test for matched pairs (pre-treatment versus post-treatment values) showed no statistical differences in any group of rats except normotensive males, then statistically significant correlations were attained in normotensive as well as in SHR/N-cp lean rats of both sexes.

On the other hand, when plasma triglycerides are taken into consideration and we are analyzing data in SHR/N-cp lean males and in SHR/N-cp obese females, then statistically significance of correlation coefficient is missing, the statistically significance in Wilcoxon test for matched pairs was attained and this significance is in accordance with the ambivalent princip, i.e., pre-treatment $\mathrm{x}=0.74 \pm 0.13$ $\mathrm{mmol} / 1$ in SHR/N-cp lean males is accompanied by $+84 \%$ increase which is done by terguride treatment, and vice versa, pre-treatment $x=7.22 \pm 1.30 \mathrm{mmol} / 1$ in SHR/N-cp obese females is accompanied by $-57 \%$ decrease induced by terguride treatment.

The above mentioned results suggest that the effect of long lasting terguride treatment is predominatly expressed in the glucose tolerance and in plasma triglycerides.

It remains to be solved the cases where profound effect of terguride is present ( see plasma triglycerides in $\mathrm{SHR} / \mathrm{N}$ cp lean males and SHR/N-cp obese females) and where the correlation between pre-treatent values and the terguride effect expressed in percent does not attain statistical significance. Some words to insulinemia in the normotensive rats of both sexes.It is apparent that terguride is potent to increase plasma insulin very profoundly in the mentioned type of rats. When we omit the fact that this finding is in line with the ambivalent princip of the terguride treatment, then the insuline increase suggest possible relation to the parallel increase in plasma triglycerides in the mentioned type of animals.

It is accepted that insulin increases triglyceride stores. Increased entry of glucose into adipose tissue facilitates fatty acid and glycerophosphate synthesis, which, by mass action, drives triglyceride synthesis. In addition, insulin inhibits the enzyme which catalyses triglyceride break down (6).

In Table 2 we have demonstrated in the normotensive rats of both sexes that the long lasting terguride treatment induced increase of insulin $(+39 \%$ in males and $38 \%$ in females) and at the same time this drug increases in normotensive rats the plasmatic triglycerides $(+17 \%$ in males and $30 \%$ in the females).The same can be found in SHR/N-cp males, i.e.,there the terguride increases insulinemia $(+30 \%)$ and plasma triglycerides $(+30 \%)$ as well. On the other hand, terguride does not change insulinemia in SHR/N-cp lean females and in SHR/N-cp obese females which is accompanied by decrease of plasma triglycerides in the former $(-28 \%)$ as well as in the later $(-57 \%)$ group of animals. In 
SHR/N-cp obese males tergutide decreases insulinemia $(-26 \%)$ and decreases plasma triglycerides $(-17 \%)$. The mentioned data are in agreement with the ambivalent princip of the terguride effect. Moreover, these data suggest a possible causal relationship between ambivalent effect of terguride on insulinemia on one side, and on plasma triglycerides on the other side. Thus, under the long lasting terguride treatment the changes of triglycerides can be considered as a consequence of the primary changes of insulinemia.This working hypothesis is in accordance with a recent conception of the role of insulin in the increase of triglyceride stores. But the causal relationship between elevation of insulinemia and increases of plasma triglycerides must be controlled in the father series of experiments. Nevertheless, data obtained in the normotensive rats of both sexes and in SHR/N-cp lean males suggest that long lasting terguride treatment is potent to increase insulinemia.To what extent this reality can be utilized in clinical practice it ramains to be solved.

\section{Acknowledgement}

This paper was supported by Internal Grant Agency of Ministry of Health of the Czech Republic No 3684-3. The authors wish to thank Carl T.Hansen, Animal Genetics Division, National Institute of Health, Bethesda, USA, for providing the genetically hypertensive rats of Koletsky type and G.W.Ashe, Imperial Chemistry Industry, Ltd., Pharmacological Division, Macclesfield, U.K., for providing normotensive rats of Han-Wistar strain.

\section{References}

1. Dixon WJ in Wissenschaftliche Tabellen, Ciba-Geigy, AG, Basel 1971:53.

2. Golda V, Petr R. Dopaminergic mechanism and genetic factor in blood pressure regulation. Sb Ved Pr Lek Fak Karlovy Universisty Hradec Králové 1982;25:419-27.

3. Golda V, Cvak L. Terguride but not bromocriptine alleviated glucose tolerance abnormalities and hyperlipemia in obese and lean genetically hypertensive Koletsky rats. Physiol Res 1994;43:299-305.

4. Golda V, Cvak L. Ambivalent effect of terguride on glucose tolerance. Physiol Res 1995;44:14P.

5. Koletsky S. Pathologic findings and laboratory data in a new strain of hypertensive rats. Am J Pathol 1975;80:12940.

6. Vander AJ, Sherman JH, Luciano DS Human Physiology, The mechanism of body function, McGrawHill, Inc., New York, 1975:399.

Submitted December 1997.

Accepted January 1998.

Doc. MUDr. PhDr. Věroslav Golda, CSc., Institute of Experimental Neurosurgery, Charles University, Faculty of Medicine and Teaching Hospital, 50005 Hradec Králové, Czech Republic. 